\title{
Test-taking Strategies \& Performance on Reading Comprehension Tests by Iranian EFL Learners
}

\author{
Natasha Pourdana (Corresponding author) \\ Department of English Translation, Faculty of Literature and Foreign Languages \\ Islamic Azad University, Karaj Branch P.O. Box: 31485-313, Karaj, Iran \\ E-mail: Natasha.qale@gmail.com \\ Fatemeh Bornaki \\ Department of English Translation, Islamic Azad University, Karaj Branch \\ Islamic Azad University, Karaj Branch, Iran \\ Zahra Moayedi Fard \\ Department of English Translation, Islamic Azad University, Karaj Branch \\ Islamic Azad University, Karaj Branch, Iran \\ Sayyed Yahya Sarkhosh \\ Department of English Translation, Islamic Azad University, Karaj Branch \\ Islamic Azad University, Karaj Branch, Iran
}

Received: 12-05- 2012

doi:10.7575/ijalel.v.1n.2p.138
Accepted: 18-06- 2012

Published: 01-07- 2012

\begin{abstract}
This study attempted to explore the possible relationship between test-taking strategies and (a) successful performance on English as a Foreign Language (EFL) reading comprehension, (b) EFL learners' level of language proficiency. To accomplish the purpose of this study, 68 students of English translation of both genders were randomly selected and placed in the three Beginner, Intermediate and Advanced levels, at Alborz Institute for Higher Education, Qazvin, Iran. Analysis of Variances (ANOVA) proved that there was a significant and positive correlation between the scores in reading comprehension test and Oxford Placement Test. While the scores in reading comprehension test did not show any significant correlations with using the majority of test-taking strategies, they had a relatively low and negative but significant correlation with test management strategy. The findings in this study were interpreted as the low knowledge of test-taking strategies in Iranian EFL context and the importance of attending to the cognitive processes effective in taking language tests was emphasized.
\end{abstract}

Keywords: Test-taking, Strategies, EFL, Reading Comprehension, Proficiency level

\section{Introduction}

Language test results may play a highly significant role in the respondents' life. In many situations, the results of language tests are used to provide information for making decisions about individuals. Therefore, as Cohen (2004) believes, it is critical for the language test-takers to employ strategies to enhance their performance on specific types of test items. Similarly, it is crucial for the test-developers to be aware of the strategies that test-takers may employ while taking language tests. They need, therefore, to discover and to improve what strategies test takers actively use in order to complete a test in general, and to comprehend a passage, in particular (Wurr, 2003).

Page | 138 


\section{International Journal of Applied Linguistics \& English Literature}

ISSN 2200-3592 (Print), ISSN 2200-3452 (Online)

Vol. 1 No. 2; July 2012

Cohen and Upton (2007) define test-taking strategies as those cognitive processes the respondents have selected and are conscious of, at least in some degree. Concerns for strategies in performing language tests, are about three aspects of (a) language learners' strategies, (b) test-management strategies, and (c) test-wiseness strategies (Phakiti, 2010a; Phakiti, 2010b).

A skilful reader constantly shifts from one processing mode to another while reading a text. Moreover, a good reader uses a variety of skills and strategies to achieve certain goals in a reading test. Individual success in using effective test-taking strategies in EFL reading comprehension depends highly on a variety of factors, including meta-cognitive strategies, text types, test-wiseness and language proficiency level (Cohen, 2009; Verenzub \& Wang, 2008; Hirano, 2009; Fewel, 2010). A theme highlighted in several researches is the frequency with which certain strategies are utilized by respondents at different proficiency levels. Findings prove different results for respondents at different proficiency levels using similar test-taking strategies (Imtiaz, 2010).

In EFL reading comprehension tests, as Oxford (2010) states, readers actively control the hidden processes while this control affects their ability to understand and learn from texts. This control is called metacognition (Block, 1992) which is the ability to stand back and observe oneself. Similarly, Brown (2007) emphasizes metacognition as a term used in information processing theories to indicate an executive function or a set of strategies that involves monitoring of production or comprehension, or generally, self-evaluating language learning processes.

Block (1992) refers to the thoughts that wander through the readers' minds in actively searching for meaning whereas they are hidden from the outside observers. He also argues for the process-oriented descriptions to be obtained from the respondents through verbal protocols. As Brown (2007) states, utilization of self-reporting data permits the researchers to have a better understanding of what test takers actually do when they take tests, and hence, what it is language tests actually measure. It is clear that research in this field has a great deal of potential for construct validation of language tests.

Nowadays, examining the validity or usefulness of a language test requires also attention to how the test takers arrive at their answers and the test-taking processes respondents employ while taking a test. They must acquire strategies for dealing with unknown or difficult words in a text that block comprehension. This word-attack skill includes top-down and bottom-up strategies wherein understanding syntax, recognizing text organization and interpreting discourse markers play critical roles, especially in reading and listening comprehension (Cubuku, 2010). Chastain (1988) concludes that the act of comprehending is essentially meaning-driven, holistic, top-down behaviour that is highly selective in the features it incorporates.

Three decades ago, as Cohen (2009) explains, language assessment research was focused mainly on the outcome of testing. Issues related to test takers were almost neglected. He comments that "What was missing was the aspect of test validation that related to test-takers' behaviors in taking the tests" (Cohen, 2009), and the processes which they employ during taking tests. It was a little known about what test-takers were actually doing to produce answers to questions. Therefore, investigating the possible impacts of test-taking strategies on successful reading comprehension by Iranian EFL learners at different levels of language proficiency was the main concern in this study. To fulfil the purpose of this study, the following questions were raised:

1. Is there any relationship between the use of test-taking strategies and the EFL learners' performance on reading comprehension tests?

2. Is there any relationship between using test-taking strategies and the English proficiency level of the learners?

Test designers may use the results in this study to develop better tests while they are aware of the strategies and processes students employ during a test. The format and aim of the test may also change when further research is done in this field. 


\section{Method}

\subsection{Participant}

Participants in this study were 68 female and male university students majoring in English translation at Alborz Institute for Higher Education, Qazvin, Iran. The participants' genders as a controlling factor modified the sampling procedure so that three Beginner, Intermediate and Advanced groups of female and male university students took part in Oxford Placement Test, a reading comprehension test and a self-evaluation questionnaire on test-taking strategies.

Ninety university students majored in English translation were selected as the intended sample in this study. All of them had taken a national university entrance exam in order to gain university admission and had passed their reading comprehension courses prior to participating in the current study. An Oxford Placement Test (OPT) was administered for the purpose of homogenizing the participants and also dividing them into three groups of advanced and intermediate and beginners. After homogenizing and applying the mortality effect, 68 participants remained who eventually participated in all study.

The total scores in OPT helped the researcher to divide participants into three groups of different proficiency levels. The range of the scores was divided into three and the gained number was added to the minimum score in OPT in order to have three different ranges of scores. So that, $22.1 \%(\mathrm{n}=15)$ of the subjects were labelled as Beginners, $44.1 \%(n=30)$ as Intermediate, and 33.8\% $(n=23)$ as Advanced.

\subsection{Research Design and Instrumentation}

The design of this study was ex post facto. In the process of conducting the present study, (a) a placement test, (b) a reading comprehension test, and (c) a questionnaire on test-taking strategies were conducted as instruments of this study.

Oxford Placement Test consisted of 50 multiple choice items, testing the proficiency level of EFL learners. In order to determine the reliability of the placement test results, Cronbach's Alpha test was conducted for the total number of test items. The obtained Cronbach $\alpha=.726$, significant at $\mathrm{p}$-value $<0.05$, demonstrated the relative consistency of the participants' performance on total test items.

The reading comprehension test consisted of 25 items. The test is available in Appendix A and was taken from Oxford official website. It consisted of a cloze passage followed by 10 questions. It was a short text entitled as "Good Walks". Options a, b, c, or d were available for individual blanks in the cloze passage. Items 11 to 17 followed another short passage entitled as "Young Farmer". For every item, participants could choose "Right" or "Wrong", and if there was not enough information to answer "Right" or "Wrong", subjects could choose "Doesn't say". Finally, items 18 to 25 were reading comprehension questions followed a six-paragraph passage entitled as "On Walden Pond". Options a, b, c, or d were available for every item. In order to determine the reliability of the reading comprehension test results, Cronbach's Alpha test was conducted for the total number of test items. The obtained Cronbach $\alpha=.732$, significant at p-value $<0.05$, demonstrated the relative consistency of the participants' performance on total reading comprehension test items.

The questionnaire on test-taking strategies was developed from an article by Cohen and Upton (2007) (Appendix B). The participants were asked to go through a 5-point Likert scale on test-taking strategies with 0 for never, 1 for rarely, 2 for sometimes, 3 for frequently and 4 for always. The questionnaire consisted of 11 statements on approaches to reading an English passage, 6 statements on using text clues to comprehend the main ideas in the passage, 11 statements on scanning the specific information and the discourse markers in the text, 28 statements on test management strategies, and 3 final statements on test-wiseness strategies. For the purpose of better understanding the statements in the questionnaire by Iranian EFL students and to sustain its validity, the questionnaire was translated into its Persian by the researchers. To analyse the participants' choices in 58 statements, values $0,1,2,3$, and 4 were given respectively to a five-point Likert scale, 'never,' 'rarely,' 'sometimes,' frequently,' and 'always'. To determine the reliability of the questionnaire, Cronbach's Alpha was performed for 59 items. The obtained Cronbach $\alpha=.912$, significant at $p$-value $<0.05$, demonstrated the high consistency of the participants' performance on test-taking strategy questionnaire. 


\section{International Journal of Applied Linguistics \& English Literature}

ISSN 2200-3592 (Print), ISSN 2200-3452 (Online)

Vol. 1 No. 2; July 2012

\section{Results and discussion}

The present study was carried out to investigate (a) the relationship between the use of test-taking strategies and the performance on EFL reading comprehension tests, and (b) the relationship between using test-taking strategies and the proficiency level of the respondents. The scores obtained in Oxford Placement Test are summarized in Table 1.

Table 1. Descriptive Statistics for OPT

\begin{tabular}{cccccc}
\hline Group & $\mathrm{N}$ & Min. Score & Max . Score & Mean Score & SD \\
\hline Female & 51 & 18.67 & 71.33 & 47.49 & 12.51 \\
Male & 17 & 21.33 & 68.7 & 44.90 & 14.38 \\
Total & 68 & 18.67 & 71.33 & 46.84 & 12.94 \\
\hline
\end{tabular}

As presented in Table 1, female participants came up with the minimum score of 18.67 and maximum score of 71.33, while male participants obtained the minimum score of 21.33, and maximum score of 68.67. The higher mean score of 47.49 for females was interpreted as their better performance on Oxford English Placement Test, while the lower standard deviation of 12.51 proved more homogeneity in female participants. In the next stage, the scores for reading comprehension test by three participant groups were analyzed and summarized in Table 2 .

Table 2. Descriptive Statistics for Reading Comprehension Test

\begin{tabular}{llllll}
\hline Group & $\mathrm{N}$ & Min. Score & Max . Score & Mean Score & SD \\
\hline Advanced Group & & & & & \\
Female & 18 & 26.67 & 78.67 & 55.25 & 13.7 \\
Male & 4 & 2.33 & 70.67 & 47.66 & 20.34 \\
Total & 22 & 21.33 & 70.67 & 53.87 & 14.86 \\
Intermediate Group & & & & & \\
Female & 23 & 9.33 & 68.00 & 44.92 & 14.15 \\
Male & 8 & 20.00 & 52.00 & 38.00 & 1.17 \\
Total & 31 & 9.33 & 68.00 & 43.13 & 13.82 \\
Beginner Group & & & & & \\
Female & 10 & 10.67 & 49.33 & 30.26 & 13.00 \\
Male & 5 & 20.00 & 53.33 & 33.33 & 12.75 \\
Total & 15 & 10.67 & 53.33 & 31.28 & 12.54 \\
\hline
\end{tabular}

As presented in Table 2, Advanced group with total mean score of 53.87, comparing to 43.13 for Intermediate group, and 31.28 for Beginner group had a better performance on reading comprehension test. On the other hand, except for male participants in Beginner group (Max. score=53.33, Mean score=33.31), the female participants outperformed the male ones in both Advanced and Intermediate groups.

Qualitative data in this study were obtained by administering a self-evaluation questionnaire on test-taking strategies. To investigate any significant relationship between the participants' reading comprehension, Oxford Placement Test scores, and test-taking strategy questionnaire, a test of ANOVA (analysis of variances) was conducted to compare the mean scores for three Beginner, Intermediate and Advanced groups (Table 3). 
International Journal of Applied Linguistics \& English Literature

ISSN 2200-3592 (Print), ISSN 2200-3452 (Online)

Vol. 1 No. 2; July 2012

\begin{tabular}{|c|c|c|c|c|c|c|c|}
\hline \multicolumn{2}{|c|}{ Tests } & Reading & (a) & (b) & (c) & (d) & (e) \\
\hline \multirow{4}{*}{$\begin{array}{l}\text { Oxford English } \\
\text { Placement Test }\end{array}$} & & Test & & & & & \\
\hline & Pearson & $.471(* *)$ & -.200 & .144 & .232 & -.041 & .123 \\
\hline & Correlation & & & & & & \\
\hline & $\begin{array}{c}\text { Sig. } \\
\text { (2-tailed) }\end{array}$ & .000 & .101 & .242 & .057 & .742 & .319 \\
\hline \multirow{3}{*}{$\begin{array}{c}\text { Reading } \\
\text { Comprehension } \\
\text { Test }\end{array}$} & Pearson & & -.156 & .025 & .162 & $-.250(*)$ & -.145 \\
\hline & Correlation & & & & & & \\
\hline & $\begin{array}{c}\text { Sig. } \\
\text { (2-tailed) }\end{array}$ & & .204 & .841 & .187 & .040 & .238 \\
\hline \multirow[t]{3}{*}{ (a) } & Pearson & & & $.290(*)$ & .059 & $.356(* *)$ & $.346(* *)$ \\
\hline & Correlation & & & & & & \\
\hline & $\begin{array}{c}\text { Sig. } \\
\text { (2-tailed) }\end{array}$ & & & .016 & .634 & .003 & .004 \\
\hline \multirow[t]{3}{*}{ (b) } & Pearson & & & & $.477(* *)$ & $.352(* *)$ & .071 \\
\hline & Correlation & & & & & & \\
\hline & $\begin{array}{c}\text { Sig. } \\
\text { (2-tailed) }\end{array}$ & & & & .000 & .003 & .567 \\
\hline \multirow[t]{3}{*}{ (c) } & Pearson & & & & & $.287(*)$ & .135 \\
\hline & Correlation & & & & & & \\
\hline & $\begin{array}{c}\text { Sig. } \\
\text { (2-tailed) }\end{array}$ & & & & & .018 & .272 \\
\hline \multirow[t]{3}{*}{ (d) } & Pearson & & & & & & $.673(* *)$ \\
\hline & Correlation & & & & & & \\
\hline & $\begin{array}{c}\text { Sig. } \\
\text { (2-tailed) }\end{array}$ & & & & & & .000 \\
\hline
\end{tabular}

As Table 3 presents, there was a significant and positive correlation between the scores in reading comprehension test and Oxford Placement Test $(\mathrm{r}=.471)$ at $\mathrm{p}$-value $<0.01$. While the scores in reading comprehension test did not show any significant correlations with Section (a), (b), (c) and (e), they had a relatively low and negative but significant correlation with Section (d) or test management strategies. In other words, participants with higher reading comprehension scores manipulated less effective test management strategies.

Considering the correlations among five sections of test-taking strategies questionnaire, as Table 4 displays, significant and positive correlations were observable between Section (a) or approaches to reading an English reading passage, Section (b) or using text clues to comprehend the main ideas in the passage ( $r=.290)$, Section (d) or test management strategies $(r=.356)$, and Section (e) or test-wiseness strategies ( $r=.346)$. Section (b) had significant and positive correlations with Section (c) or scanning the specific information and the discourse markers in the text $r=.477$, and Section (d) $r=.352$, respectively. Section (C) only had a significant and positive correlation with Section (d) r=.278. Finally, Section (d) had a highly significant and positive correlation with Section (e) $r=.673$.

Finally, to locate the differences in the performance of three Beginner, Intermediate and Advanced groups on test-taking strategies questionnaire, a test of ANOVA was administered (Table 4). 
International Journal of Applied Linguistics \& English Literature

ISSN 2200-3592 (Print), ISSN 2200-3452 (Online)

Vol. 1 No. 2; July 2012

Table 4. OPT and Test-taking strategies questionnaire

\begin{tabular}{ccccccc}
\hline Section & & $\begin{array}{c}\text { Sum of } \\
\text { Squares }\end{array}$ & df & Mean Square & F & Sig. \\
\hline (a) & Between Groups & 639.11 & 2 & 319.55 & 2.305 & .108 \\
& Within Groups & 9010.12 & 65 & 138.61 & & \\
(b) & Between Groups & 690.78 & 2 & 345.39 & 1.057 & .353 \\
& Within Groups & 21233.57 & 65 & 326.67 & & .002 \\
(c) & Between Groups & 1976.21 & 2 & 988.11 & & .232 \\
& Within Groups & 9669.97 & 65 & 148.76 & $6.642(* *)$ & 1.494 \\
(d) & Between Groups & 425.27 & 2 & 212.63 & & .345 \\
& Within Groups & 9253.27 & 65 & 142.35 & & \\
(e) & Between Groups & 850.17 & 2 & 425.08 & 1.082 & \\
& Within Groups & 25532.49 & 65 & 392.80 & & \\
\hline
\end{tabular}

**Correlation is significant at the 0.01 level (2-tailed). *Correlation is significant at the 0.05 level (2-tailed).

As Tables 4 indicates, performance of Beginner, Intermediate and Advanced groups were not significantly different on five sections of test-taking strategies questionnaire, except for Section (c) or scanning the specific information and the discourse markers in the text $(\mathrm{F}=6.642)$ significant at $\mathrm{p}$-value $<0.01$.

The present study was set up to scrutinize and determine the effective strategies and cognitive processes which test-takers employ during the tests. According to Cohen (2006), test validity requires attention to how the test-takers arrive at their answers and what processes they employ in order to answer the questions. This study supported a strong relationship between a successful performance on reading comprehension tests and language proficiency levels of Iranian EFL learners. The use of test-taking strategies may be the same among different proficiency levels, but according to Cohen (2009) there should be a qualitative difference in how they use them.

\section{Conclusion}

In this study, successful English reading comprehension, however, seemed relatively independent from the active and efficient employment of test-taking strategies, except for test management strategies. It could be interpreted as the low knowledge of the respondents of how to utilize test-taking strategies in order to enhance their performance on the test. In EFL assessment in Iran, therefore, due to the gradual shift of focus from the final scores to the employed cognitive processes and strategies, the importance of the strategies employed is highlighted. Since in Iranian educational systems, as Cohen 2009 confirms, the results of different tests are largely used to provide information for making decision about individuals; therefore it is critical to discover and teach the best and most efficient strategies which successful test-takers employ.

As a limitation in this study, the researchers collected data on test-taking strategies via a questionnaire in order to assess the participants' mental processes. The data were strongly reliant on test-takers' own accounts; and surely the mentioned questionnaire was developed according to the matter of time, context, and purpose of the study. Further research with the use of verbal reports and detailed observations may be replicated in order to asses more valid and reliable data about the mental processes of the test-takers. More qualitative studies may be replicated for the purpose of investigating test-taking strategies.

\section{References}

Block, E. (1992). See how they read: Comprehension monitoring of L1 and L2 readers. TESOL Quarterly. 26(2), pp. 319-343.

Brown, H. D. (2007). Principles of language learning and teaching (5 ${ }^{\text {th }}$ ed.). New York: Pearson Education Press.

Chastain, K. (1988). Developing second language skills ( $3^{\text {rd }}$ ed.). United States: Harcourt Brace Jovanovich Inc. 
International Journal of Applied Linguistics \& English Literature

ISSN 2200-3592 (Print), ISSN 2200-3452 (Online)

Vol. 1 No. 2; July 2012

Cohen, A. D. (2009a). The coming of age of research on test-taking strategies. Retrieved from http://www.tc.umn.edu/ adcohen/Cohen\%20articles/2006\%20-\%20Test-Taking\%20Strategies\%20LAQ.pdf>

Cohen, A. D. (2009b). Coming to terms with language learner strategies: What do strategy experts think about the terminology and where would they direct their research? Retrieved from http://www.crie.org.nz/research_paper/Andrew\%20Cohen\%20WP12.pdf

Cohen, A. D. \& Upton, T.A. (2007). I want to go back to the text: Response strategies on the reading subtest of the New TOEFL. Language Testing. 24(3), pp. 209-250.

Cubuku, F. (2010) How to enhance reading comprehension through metacognitive strategies. Retrieved from http://www.sosyalarastirmalar.com/cilt1/sayi2/sayi2pdf/cubukcu_feryal.pdf

Fewell, N. (2010). Language learning strategies and English language proficiency: an investigation of Japanese EFL university students. Retrieved from http://www.tesol-journal.com/PDF/A11V2_TESOL.pdf

Hirano, K. (2009). Research on test-taking strategies in L2 reading. Retrieved from http://www.lib.juen.ac.jp/db/14_hira.pdf

Imtiaz, Sh. (2010). Metacognitive strategies of reading among ESL learners. Retrieved from http://salr.net/Documents/Shagufta.pdf

Oxford, R. L. (2010). Language learning styles and strategies: An overview. Retrieved from http://web.ntpu.edu.tw/ language/workshop/read2.pdf

Phakiti, A. (2010a). Modeling cognitive and metacognitive strategies and their relationships to EFL reading test performance. Retrieved from http://www.ltrc.unimelb.edu.au/mplt/papers/11_1_4_Phakiti.pdf

Phakiti, A. (2010b). Construct validation of Bachman and Palmer's (1996) strategic competence model over time in EFL reading tests. Retrieved from http://202.197.121.116/Downloads/LangTst/tst_006.pdf

Verezub, E. \& Wang, H. (2010). The role of metacognitive reading strategies instructions and various types of links in comprehending hypertext. Retrieved from http://www.ascilite.org.au/conferences/melbourne08/procs/verezub.pdf

Wurr, A. J. (2003). Reading in a second language: A reading problem or a language problem? Journal of College Reading and Learning. 33(2), pp. 157-170. 


\section{Reading Comprehension Test}

I. Read the text and choose the correct word for each space.

\section{Good walks}

You're rarely far from a good walk in Britain - ....1.... you live in the town or the country. From mountains in the North to gentle hills in the South, you're ....2.... to find some wide open spaces you will like. People .....3..... live in the city can enjoy walks .....4.... canals and in the many beautiful parks to be found.

Walking gives you the .....5.... of exercise and at the same time allows you to experience wonderful scenery. You can also ....6..... about local wildlife. On foot, in the countryside, you see much more than you'd .....7..... see from the car or on a bike.

However, if you are out in the countryside make sure you follow the rules. You mustn't go .....8.... that's private, you .....9.... stay on public footpaths and .....10.... animals in fields!
a. whether
b. While
c. Because
d. Although

2.
a. confident
b. Sure
c. definite
d. clear

3.
a. who
b. whom
c. whose
d. which

4.
a. round
b. through
c. along
d. between

5 .
a. help
b. benefit
c. assistance
d. allowance

6.
a. know
b. find
c. learn
d. look

7.
a. ever
b. never
c. yet
d. always

8.
a. any
b. anywhere
c. anyway
d. anyhow

9.
a. could
b. ought
c. would
d. should

10.
a. stay
b. avoid
c. keep
d. let 
II. Read the article about Gavin Clark, a young farmer. For each question (11-17), Choose 'Right' if the sentence is correct or choose 'Wrong' if the sentence is not correct. If there is not enough information to answer 'Right' or 'Wrong', choose 'Doesn't say'.

\section{Young farmer}

At the age of four, Gavin Clark knew the names of each one of his neighbour's cows. By ten, he was selling milk and cheese to other neighbours, and was winning prizes at farm shows. Now, at thirteen, he still loves farming and has his own animals. Presents for Gavin are not a problem - every year he gets another animal from his parents and brother.

Gavin's father, Steven, works for an international company and travels all over the world. Gavin has visited many exciting places in Europe with his father. But he is much happier spending each weekend working on his neighbour's farm! Steven's company wanted him to move to Portugal with the family. Everyone liked the idea of living in a new country - but not Gavin! He said he wouldn't leave his animals!

In his free time, Gavin plays tennis and football. He goes out with his friends and enjoys computer games, just like other teenagers. But every morning, he gets up at half past five to give his animals food and water, before he goes to school. His parents want him to go to college and get a diploma when he is sixteen. 'Let's wait and see,' he says, 'because I will have my own farm by then!'

11. Gavin's family never know what presents to give him.
a. Right
b. Wrong
c. Doesn't say

12. Steven enjoys working in different countries.
a. Right
b. Wrong
c. Doesn't say

13. On Saturdays and Sundays, Gavin has a job near his home.
a. Right
b. Wrong
c. Doesn't say

14. Gavin didn't agree with his parents about moving to Portugal.
a. Right
b. Wrong
c. Doesn't say

15. Gavin is too busy with his animals to have any other hobbies.
a. Right
b. Wrong
c. Doesn't say

16. Mr. and Mrs. Clark get up at the same time as Gavin in the morning.
a. Right
b. Wrong
c. Doesn't say

Page | 146 
International Journal of Applied Linguistics \& English Literature

ISSN 2200-3592 (Print), ISSN 2200-3452 (Online)

Vol. 1 No. 2; July 2012

17. Gavin has decided to study for a diploma at college.
a. Right
b. Wrong
c. Doesn't say.

III. Choose the correct answer. a, b, c, or d.

\section{On Walden Pond}

1 During his lifetime, Henry David Thoreau wrote over twenty books - travel books, books of poetry, and collections of essays - but none has had such a lasting influence as Walden, an account of the time he spent in a tiny house on the shore of Walden Pond near Concord, Massachusetts. Born in 1817 in Concord, Thoreau graduated from Harvard University in nearby Cambridge, Massachusetts. When he returned to Concord, he worked for his father, who manufactured pencils, and tutored the children of writer Ralph W. Emerson, Thoreau's friend and mentor. Thoreau then decided to move to a relatively isolated one-room cabin in the woods just outside of Concord on land owned by Emerson. Thoreau began clearing the land and building the cabin in the spring of 1845 and, perhaps significantly, he chose to move in on July 4 of that year-on the holiday celebrating the independence of the United States in 1776. He lived on the pond for two years, but in Walden, he compresses that time into a single year.

2 Thoreau wrote in Walden, "I went to the woods because I wished to live deliberately ... and not, when I came to die, discover that I had not lived." Essentially, Walden is Thoreau's description of an experiment in self-reliance and in living the simple life. He believed that owning anything beyond the basic necessities of life was an obstacle to a happy life rather than an advantage. He wrote, "I see young men ... whose misfortune it is to have inherited farms, houses, barns, cattle, and farming tools; for these are more easily acquired than got rid of." He built his own house for a mere $\$ 28.13$ (about $\$ 300.00$ in today's dollars). He grew beans and other vegetables, which he sold for a modest profit. In Walden, he includes a rather lengthy, detailed reckoning of how much he spent and how much he earned, information which some readers find tedious. He spent the rest of his time at the pond walking in the woods, reading, and writing a book about a canoe trip with his brother, A Week on the Concord and Merrimack Rivers.

3 Although Thoreau valued solitude and spent much time alone, he was not completely cut off from society. His cabin was close to the road to Concord and he often walked to town to do business and have dinner with family or friends. He entertained visitors at his cabin and his mother sometimes brought him meals. Richard Zachs, a contemporary critic, says that it was like "suburban boys going to their tree house in the backyard and pretending they're camping in the heart of the jungle."

4 Thoreau had an ambivalent attitude towards technology. He invented a method of making pencils from low-grade clay for use in his father's factory. But he was suspicious of the greatest technological innovations of his time, the telegraph and the railroad. He pointed out in Walden that the nation was hastily building a telegraph system that would soon link the country from Maine to Texas, but Thoreau said "Maine and Texas, it may be, have nothing important to communicate." He believed that trains gave people an illusion of freedom, but in fact represented a new servitude, because it meant obeying fixed train schedules and routes. He also wrote that he found a "train" of clouds moving across the sunrise of much more interest than a train of railroad cars going to Boston.

5 Thoreau was a dedicated student of nature. Walden is filled with minute observations of animals, plants, and weather. He wrote, "For years I was a self-appointed inspector of snowstorms and rainstorms." When writing about animals, he would relate their behavior to that of humans, as in his fascinating account of war between red and black ants. His writings about the "interconnectedness" of nature anticipate the environmental movement by about 125 years.

Page | 147 


\section{International Journal of Applied Linguistics \& English Literature}

ISSN 2200-3592 (Print), ISSN 2200-3452 (Online)

Vol. 1 No. 2; July 2012

6 Like his fellow New Englander, twentieth-century poet Robert Frost, Thoreau wrote in a style that seems folksy on the surface, but it contains wit and symbolism. Thoreau sprinkled his prose with classical allusions as well as with word play and puns, some of which are difficult for today's readers to comprehend. Thoreau can be poetic too, as when he beautifully describes ice on the pond. But despite the clarity of his writing, Walden is not an easy book, especially for first time readers. It has no plot line, no real characters outside of Thoreau himself, and even the most enthusiastic Thoreau admirer would probably agree that some of his descriptions of ponds, woods and storms go on too long. But it is an important book, and definitely worth the effort.

18. What does the author say in paragraph 1 about the date July 4, 1845 ?

a. Thoreau possibly decided to move on that day because it was Independence Day.

b. Thoreau was not able to move on that date because it was a national holiday.

c. Thoreau began to construct his cabin near Walden Pond on that day.

d. Thoreau agreed to buy land on Walden Pond from Emerson on that date.

19. The phrase that time in the passage is a reference to the
a. single year that Thoreau describes in his book
b. spring and summer of 1845
c. two years that Thoreau spent at Walden Pond
d. period between 1776 and 1845

20. Which of the sentences below best expresses the essential information in the highlighted sentence in paragraph 2 ? (Incorrect answer choices change the meaning in important ways or leave out essential information.)

a. He felt that acquiring the necessities of life was the best way to live happily.

b. He thought that the ownership of unnecessary possessions would not lead to happiness.

c. He believed that owning things was a basic necessity for a happy existence.

d. He realized that owning even the basic necessities could serve as an obstacle to happiness.

21. The word tedious in the passage is closest in meaning to .... .
a. memorable
b. insignificant
c. uninteresting
d. humorous

22. In paragraph 2, the author does NOT mention that Thoreau engaged in which of these activities while at Walden Pond?
a. Growing his own food
b. Going for walks in nature
c. Selling vegetables
d. Writing the book Walden

23. The author probably quotes the critic Richard Zachs in paragraph 3 in order to
a. emphasize that Thoreau was not completely isolated
b. express how difficult life was for Thoreau in the cabin
c. give another reason why Thoreau moved to Walden Pond
d. explain why people enjoy getting away from civilization

24. The word ambivalent in the passage is closest in meaning to
a. resolved
b. clear
c. unrealistic
d. mixed

Page | 148 
International Journal of Applied Linguistics \& English Literature

ISSN 2200-3592 (Print), ISSN 2200-3452 (Online)

Vol. 1 No. 2; July 2012

25. The author describes Thoreau's style of writing in paragraph 6 in part by ..... .

a. showing that it was similar to that of other writers of his time

b. comparing it to the style of a more recent writer

c. providing examples of his wit and symbolism

d. showing how he was influenced by other New England writers

http://www.oxfordenglishtesting.com

\section{APPENDIX B}

Test-Taking Strategies Questionnaire

\section{English Version}

1. I plan a goal for the passage

Always 100\% Frequently 75\% Sometimes 50\% Rarely 25\% Never 0\%

2. I make a mental note of what is learned from the pre-reading

Always 100\% Frequently 75\% Sometimes50\%Rarely 25\% Never 0\%

3. I consider prior knowledge of the topic.

Always $100 \%$ Frequently $75 \% \quad$ Sometimes $50 \% \quad$ Rarely $25 \% \quad$ Never $0 \%$

4. I read the whole passage carefully.

Always $100 \%$ Frequently $75 \% \quad$ Sometimes $50 \% \quad$ Rarely $25 \% \quad$ Never $0 \%$

5. I read the whole passage rapidly.

Always $100 \%$ Frequently $75 \% \quad$ Sometimes $50 \% \quad$ Rarely $25 \% \quad$ Never $0 \%$

6. I read a portion of the passage carefully.

Always $100 \%$ Frequently $75 \% \quad$ Sometimes $50 \% \quad$ Rarely $25 \% \quad$ Never $0 \%$

7. I read a portion of the passage rapidly looking for specific information.

Always $100 \%$ Frequently $75 \%$ Sometimes $50 \%$ Rarely $25 \% \quad$ Never $0 \%$

8. I look for markers of meaning in the passage (e.g., definitions, examples, indicators of key ideas, etc.)
Always $100 \%$ Frequently $75 \%$
Sometimes $50 \%$
Rarely $25 \% \quad$ Never $0 \%$

9. I repeat, paraphrase, or translate words, phrases, or sentences - or summarize paragraphs/passage - to aid or improve understanding.
Always $100 \%$ Frequently $75 \%$
Sometimes $50 \%$
Rarely 25\% Never 0\%

10. I identify an unknown word or phrase.

Always $100 \% \quad$ Frequently $75 \%$ Sometimes $50 \% \quad$ Rarely $25 \% \quad$ Never $0 \%$

11. I identify unknown sentence meaning.

Always $100 \%$ Frequently $75 \%$ Sometimes $50 \%$ Rarely $25 \% \quad$ Never $0 \%$

12. During reading, I reread to clarify the idea.

Always $100 \%$ Frequently $75 \% \quad$ Sometimes $50 \% \quad$ Rarely $25 \% \quad$ Never $0 \%$

13. During reading, I ask myself about the overall meaning of the passage/portion.
Always $100 \%$ Frequently $75 \%$
Sometimes $50 \%$
Rarely $25 \%$ Never $0 \%$

14. During reading, I monitor understanding of the passage/portion's discourse structure (e.g., compare/contrast, description, definition).

Always $100 \%$ Frequently $75 \% \quad$ Sometimes $\quad 50 \% \quad$ Rarely $25 \% \quad$ Never $0 \%$

Page | 149 


\section{International Journal of Applied Linguistics \& English Literature \\ ISSN 2200-3592 (Print), ISSN 2200-3452 (Online)}

Vol. 1 No. 2; July 2012

15. I adjust comprehension of the passage as more is read: Ask myself if previous understanding is still accurate given new information.
Always $100 \%$ Frequently $75 \%$
Sometimes $50 \%$
Rarely $25 \%$ Never $0 \%$

16. I adjust comprehension of the passage as more is read: I identify the specific new information that does or does not support previous understanding.
Always $100 \%$ Frequently $75 \%$
Sometimes $50 \%$
Rarely $25 \%$
Never $0 \%$

17. I confirm final understanding of the passage based on the content.
Always $100 \%$
Frequently $75 \%$
Sometimes $50 \%$
Rarely $25 \%$
Never $0 \%$

18. I use the terms already known in building an understanding of new terms.
Always $100 \%$ Frequently $75 \%$
Sometimes $50 \%$
Rarely $25 \% \quad$ Never $0 \%$

19. I identify and learn the key words of the passage.
Always $100 \%$ Frequently $75 \%$
Sometimes $50 \%$
Rarely $25 \%$
Never $0 \%$

20. I look for sentences that convey the main ideas.
Always $100 \%$ Frequently $75 \%$
Sometimes $50 \%$
Rarely $25 \%$
Never $0 \%$

21. I use knowledge of the passage/portion: I note the discourse structure of the passage /portion (cause/effect, compare/contrast, etc.).
Always $100 \%$ Frequently $75 \%$
Sometimes $50 \%$
Rarely $25 \% \quad$ Never $0 \%$

22. I use knowledge of the passage/portion: I note the different parts of the passage (introduction, examples, transitions, etc.) and how they interrelate ('Is this still part of the introduction or is this the first topic?' 'This sounds like a summary - is it the conclusion?').
Always $100 \%$ Frequently $75 \%$
Sometimes $50 \%$
Rarely $25 \%$ Never $0 \%$

23. I use knowledge of the passage/portion: I use logical connectors to clarify content and passage organization (e.g., 'First of all', 'On the other hand', 'In conclusion').
Always 100\% Frequently $75 \%$
Sometimes $50 \%$
Rarely $25 \%$
Never $0 \%$

24. I use other parts of the passage to help in understanding a given portion: I read ahead to look for information that will help in understanding what has already been read.
Always 100\% Frequently $75 \%$
Sometimes $50 \%$
Rarely $25 \%$
Never 0\%

25. I use other parts of the passage to help in understanding a given portion: I go back in the passage to review/understand information that may be important to the remaining passage. Always 100\% Frequently $75 \%$ Sometimes $50 \%$ Rarely $25 \%$ Never $0 \%$

26. I verify the referent of a pronoun.
Always $100 \%$ Frequently $75 \%$
Sometimes $50 \%$
Rarely $25 \%$
Never 0\%

27. I infer the meanings of new words by using work attack skills: Internal (root words, prefixes, etc.).
Always $100 \%$ Frequently $75 \%$
Sometimes $50 \%$
Rarely $25 \%$ Never $0 \%$

28. I infer the meanings of new words by using work attack skills: External context (neighboring words/sentences/overall passage).
Always $100 \%$ Frequently $75 \%$
Sometimes $50 \%$
Rarely $25 \%$
Never $0 \%$

29. I go back to the question for clarification: Reread the question.
Always $100 \%$ Frequently $75 \%$
Sometimes $50 \%$
Rarely $25 \%$
Never 0\%

30. I go back to the question for clarification: Paraphrase (or confirm) the question or task.
Always $100 \%$ Frequently $75 \%$
Sometimes $50 \%$
Rarely $25 \%$
Never $0 \%$

31. I go back to the question for clarification: Wrestle with the question intent.

Always $100 \%$ Frequently $75 \% \quad$ Sometimes $50 \% \quad$ Rarely $25 \% \quad$ Never $0 \%$

Page | 150 


\section{International Journal of Applied Linguistics \& English Literature}

ISSN 2200-3592 (Print), ISSN 2200-3452 (Online)

Vol. 1 No. 2; July 2012

32. I read the question and consider the options before going back to the passage/portion. Always $100 \%$ Frequently $75 \% \quad$ Sometimes $50 \% \quad$ Rarely $25 \% \quad$ Never $0 \%$

33. I read the question and then read the passage/portion to look for clues to the answer, either before or while considering options.
Always $100 \%$ Frequently $75 \%$
Sometimes $50 \%$
Rarely $25 \% \quad$ Never $0 \%$

34. I predict/ produce own answer after reading the portion of the text referred to by the question.

Always $100 \%$ Frequently $75 \% \quad$ Sometimes $50 \% \quad$ Rarely $25 \% \quad$ Never $0 \%$

35. I predict or produce own answer after reading the question and then look at the options (before returning to text).
Always 100\% Frequently $75 \%$
Sometimes $50 \%$
Rarely $25 \%$
Never $0 \%$

36. I predict or produce my own answer after reading questions that require text insertion.

Always $100 \%$ Frequently $75 \% \quad$ Sometimes $50 \% \quad$ Rarely $25 \% \quad$ Never $0 \%$

37. I consider the options and identify an option with unknown vocabulary.
Always 100\% Frequently $75 \%$
Sometimes $50 \%$
Rarely $25 \%$
Never 0\%

38. I consider the options and check the vocabulary option in context.
Always $100 \%$ Frequently $75 \%$
Sometimes $50 \%$
Rarely $25 \%$
Never $0 \%$

39. I consider the options and focus on a familiar option.

Always $100 \%$ Frequently $75 \% \quad$ Sometimes $50 \% \quad$ Rarely $25 \% \quad$ Never $0 \%$

40. I consider the options and select preliminary option(s)

Always $100 \%$ Frequently $75 \% \quad$ Sometimes $50 \% \quad$ Rarely $25 \% \quad$ Never $0 \%$

41. I consider the options and define the vocabulary option.

Always $100 \%$ Frequently $75 \% \quad$ Sometimes $50 \% \quad$ Rarely $25 \% \quad$ Never $0 \%$

42. I consider the options and paraphrase the meaning.

Always $100 \%$ Frequently $75 \% \quad$ Sometimes $50 \% \quad$ Rarely $25 \% \quad$ Never $0 \%$

43. I consider the options and drag and consider the new sentence in context.

Always $100 \%$ Frequently $75 \% \quad$ Sometimes $50 \% \quad$ Rarely $25 \% \quad$ Never $0 \%$

44. I postpone consideration of the options.

Always $100 \%$ Frequently $75 \% \quad$ Sometimes $50 \% \quad$ Rarely $25 \% \quad$ Never $0 \%$

45. I consider the options and wrestle with the option meaning. Always 100\% Frequently $75 \%$

Sometimes $50 \%$ Rarely $25 \%$ Never $0 \%$

46. I make an educated guess (e.g., using background knowledge or extra-textual knowledge).

Always $100 \%$ Frequently $75 \% \quad$ Sometimes $50 \% \quad$ Rarely $25 \% \quad$ Never $0 \%$

47. I reconsider or double check the response.

Always 100\% Frequently $75 \% \quad$ Sometimes $50 \% \quad$ Rarely $25 \% \quad$ Never $0 \%$

48. I look at the vocabulary item and locate the item in context.

Always $100 \%$ Frequently $75 \% \quad$ Sometimes $50 \% \quad$ Rarely $25 \% \quad$ Never $0 \%$

49. I select options through background knowledge.

Always $100 \%$ Frequently $75 \% \quad$ Sometimes $\quad 50 \% \quad$ Rarely $25 \% \quad$ Never $0 \%$

50. I select options through vocabulary, sentence, paragraph, or passage overall meaning (depending on item type).

Always $100 \%$ Frequently $75 \% \quad$ Sometimes $50 \% \quad$ Rarely $25 \% \quad$ Never $0 \%$

51. I select options through elimination of other option(s) as unreasonable based on background knowledge. Always $100 \%$ Frequently $75 \% \quad$ Sometimes $50 \% \quad$ Rarely $25 \% \quad$ Never $0 \%$

Page $\mid 151$ 


\section{International Journal of Applied Linguistics \& English Literature}

ISSN 2200-3592 (Print), ISSN 2200-3452 (Online)

Vol. 1 No. 2; July 2012

52. I select options through elimination of other option(s) as unreasonable based on paragraph/overall passage meaning.
Always 100\% Frequently $75 \%$
Sometimes $50 \%$
Rarely $25 \%$
Never $0 \%$

53. I select options through elimination of other option(s) as similar or overlapping and not as comprehensive Always 100\% Frequently 75\% Sometimes $50 \%$ Rarely 25\% Never 0\%

54. I select options through their discourse structure.
Always $100 \%$ Frequently $75 \%$
Sometimes $50 \%$
Rarely 25\% Never $0 \%$

55. I discard option(s) based on background knowledge.
Always 100\% Frequently $75 \%$
Sometimes $50 \%$
Rarely $25 \% \quad$ Never $0 \%$

56. I discard option(s) based on vocabulary, sentence, paragraph, or passage overall meaning as well as discourse structure.
Always $100 \%$ Frequently $75 \%$
Sometimes $50 \%$
Rarely 25\% Never $0 \%$

57. I use the process of elimination (i.e., selecting an option even though it is not understood, out of a vague sense that the other options couldn't be correct).
Always 100\% Frequently $75 \%$
Sometimes $50 \%$
Rarely $25 \%$
Never $0 \%$

58. I use clues in other items to answer an item under consideration.
Always 100\%
Frequently $75 \%$
Sometimes $50 \%$
Rarely $25 \%$
Never $0 \%$

59. I select the option because it appears to have a word or phrase from the passage in it - possibly a key word. Always $100 \%$ Frequently $75 \%$ Sometimes $50 \%$ Rarely $25 \%$ Never $0 \%$ 